\author{
Ewa JABŁońsKa, KaRina BŁąDKOwska, Monika BRONKOWsKa \\ Katedra Żywienia Człowieka \\ Uniwersytet Przyrodniczy we Wrockawiu \\ Chełmońskiego 37, 51-630 Wrockaw \\ E-mail: ewa.jablonska@upwr.edu.pl \\ karina.bladkowska@upwr.edu.pl \\ monika.bronkowska@upwr.edu.pl
}

\title{
ZABURZENIA ODŻYWIANIA JAKO PROBLEM ZDROWOTNY I PSYCHOSPOŁECZNY
}

\section{WSTEP}

Zaburzenia odżywiania (ang. eating disorders, ED) sa problemami natury psychologicznej, choć ich skutki obejmuja także sferę fizyczną i społeczną. Najczęściej diagnozowanymi zaburzeniami są: jadłowstręt psychiczny (anoreksja, ang. anorexia nervosa) i żarłoczność psychiczna (bulimia, ang. bulimia nervosa), zarówno ich postacie kliniczne, jak i subkliniczne $i$ atypowe. Inne zaburzenia odżywiania to m.in.: pica u dorosłych (łaknienie spaczone), psychogenna utrata łaknienia, ograniczanie lub unikanie przyjmowania pokarmów, zespół jedzenia nocnego, bigoreksja, ortoreksja oraz zespół kompulsywnego objadania się (WHO 2012, MichAlSKA i współaut. 2016). Niektóre z tych nieprawidłowości zostały określone jako zaburzenia odżywiania według klasyfikacji IDC-10 i/lub DSM-5, inne zaklasyfikowane sa do innych grup chorób lub obecnie nie sa rozpoznane jako samodzielne jednostki chorobowe. ED stanowia coraz bardziej powszechny problem, zwłaszcza w kulturze zachodniej, w której promowany jest wizerunek szczupłego ciała, a jednocześnie rośnie tempo życia, wymagania i presja otoczenia. Niektóre osoby moga zatracić się w pogoni za tym ideałem i wykształcić zaburzenie odżywiania, a dotyczy to przede wszystkim dziewcząt w okresie dojrzewania. Powstaje zatem pytanie, co sprawia, iż dana osoba jest podatna na wykształcenie takiego zaburzenia. Jakie czynniki biologiczne, psycholo- giczne, środowiskowe i rodzinne najbardziej predysponuja do wystapienia choroby? Czy istnieją pewne wspólne cechy wśród osób chorujacych na ED? W jaki sposób objawia się choroba i jakie powinno być postępowanie terapeutyczne?

\section{EPIDEMIOLOGIA}

Większość przypadków zaburzeń odżywiania dotyczy nastoletnich dziewczat, choć schorzenia te moga wystapić w każdym wieku i u obu płci (BATOR i współaut. 2011), bowiem 5-10\% chorych stanowia chłopcy w okresie dojrzewania (FREYBERGER i współaut. 2005).

Szacuje się, że wśród dziewcząt poniżej 18 r.ż. w Polsce problem anoreksji dotyczy $0,8-1,8 \%$, a po uwzględnieniu postaci atypowych odsetek ten sięga 3,7\% (BATOR i współaut. 2011). W populacji osób dorosłych częstość występowania jadłowstrętu to $0,5-1 \%$ u kobiet i 0,05-0,1\% u mężczyzn (LEWITT i współaut. 2008, BATOR i współaut. 2011).

Częstość zachorowań na żarłoczność psychiczna ocenia się na $1,3 \%$ w populacji osób dorosłych w Polsce i 2\% wśród młodzieży (JózEFIK 1999). Na świecie występowanie bulimii wśród kobiet wynosi 1-4\% (KAPLAN i SADOCK 2004).

Zaburzenia odżywiania dotycza przede wszystkim kultury zachodniej, co w dużej mierze zwiazane jest ze społecznym naciskiem na konieczność utrzymania szczupłej 
sylwetki, przy jednoczesnej dużej dostępności wielu rodzajów produktów spożywczych (KĘDRA i PIETRAS 2011). Poza kręgiem kultury zachodniej, zaburzenia odżywiania występują wśród przedstawicieli rasy białej zamieszkujacych tereny Afryki Południowej, a także w Japonii (BATOR i współaut. 2011).

\section{UWARUNKOWANIA WYSTAPIENIA ZABURZEN ODŻYWIANIA}

Etiologia zaburzeń odżywiania jest wieloczynnikowa i do tej pory nie została w pełni poznana, wskazuje się jednak, że ogromna rolę w ich rozwoju odgrywaja czynniki psychologiczne, rodzinne, osobowościowe, społeczno-kulturowe i genetyczne.

Obecnie w kulturze zachodniej funkcjonuje swoisty „kult ciała”. Posiadanie sylwetki zgodnej $z$ powszechnie przyjętym ideałem utożsamiane jest $z$ sukcesem. Szczupłe ciało promowane jest przez media, a młode dziewczęta, gdyż to ich w znacznej mierze dotyczy problem ED, zarzucane obrazami „sylwetki idealnej" moga odczuwać presję i zaczać się $z$ czasem $z$ nimi porównywać. Narastajace niezadowolenie $z$ własnego wygladu skłania do podjęcia diety i/lub wprowadzenia intensywnej aktywności fizycznej, a ciagła presja społeczna powoduje, że działania te przyjmuja wymiar obsesji i ostatecznie przeradzaja się w zaburzenie odżywiania (DOBRZYŃSKA i RYMASZEWSKA 2006, BRYTEK-MATERA 2008, DYCHT i MARSZAEEK 2011, GUSTEK i JAWORSKI 2011, KoszowsKA i współaut. 2013, PORYCKA 2016). Aby jednak doszło do takiej sytuacji, niezbędne jest działanie dodatkowego czynnika wyzwalajacego chorobe (DYCHT i MARSZAEEK 2011).

U osób cierpiących na ED występuja określone cechy osobowości, w tym: perfekcjonizm, skłonność do rywalizacji, niska samoocena (TOZZI i współaut. 2003, DOBRZYŃSKA i RYMASZEWSKA 2006). Wśród tych cech perfekcjonizm wydaje się być czynnikiem najsilniej predysponujaccym do wystapienia choroby. Również perfekcjonizm matek chorych osób jest uznawany za element wywołujacy ED (MIKOŁAJCZYK i SAMOCHOWIEC 2004). Często obserwowane sa zachowania neurotyczne i obsesyjno-kompulsywne. ED nierzadko skojarzone sa $z$ zaburzeniami osobowości, przy czym zazwyczaj diagnozuje się osobowość $z$ cechami lękowymi lub $z$ zaburzeniami emocjonalnymi (TozzI i współaut. 2003, MiKOŁAJCZYK i SAMOCHOWIEC 2004, BATOR i współaut. 2011). Poza wymienionymi cechami, również słabe ukierunkowanie charakteru skojarzono $z$ występowaniem ED (MikOŁAJCZYK i SAMOCHOWIEC 2004).

Kolejnym aspektem istotnym w etiologii zaburzeń odżywiania sa relacje rodzinne.
Wśród nieprawidłowości w stosunkach rodzinnych wymienia się m.in.:

- nadopiekuńczość rodziców, utrudniająca uzyskanie samodzielności przez dziecko i promujaca wykształcenie postawy bezradności wobec świata zewnętrznego;

- wysokie oczekiwania wobec dziecka ze strony rodziców, wywołujące presję spełnienia wszelkich ich życzeń oraz norm społecznych, także dotyczacych wyglądu;

- angażowanie dziecka w konflikt pomiędzy małżonkami, co sprawia, że dziecko czuje winę za problemy rodziców;

- unikanie konfliktów i wszelkich trudnych sytuacji mogacych zagrozić harmonii rodziny, co sprzyja wykształceniu postawy biernej i prowadzi do tego, że dziecko nie potrafi rozwiązywać swoich problemów (DOBRZYŃSKA i RYMASZEWSKA 2006, LEWITT i wspó1aut. 2008, BATOR i współaut. 2011, NowAK 2013).

Na zaburzenia odżywiania częściej choruja osoby pochodzace $z$ rodzin, w których wcześniej występowały podobne schorzenia oraz otyłość, zaburzenia osobowości, fobie społeczne, depresja, nadużywanie alkoholu lub substancji psychoaktywnych, stres pourazowy i inne zaburzenia na tle psychicznym i psychologicznym. Wystapieniu ED sprzyja też stosowanie diety przez cała rodzinę celem uzyskania lub utrzymania określonej sylwetki przez wszystkich jej członków (TOZzI i współaut. 2003, NowAK 2013). Opisane nieprawidłowości w relacjach rodzinnych sprawiaja, że dziecko odczuwa brak własnej przestrzeni i prywatności, a swoje ciało traktuje jako ostatnią rzecz, nad którą może mieć kontrolę. Rodzaj sytuacji rodzinnej może warunkować typ wykształconego zaburzenia odżywiania. W rodzinach anorektyczek zaobserwowano dystans pomiędzy małżonkami, którzy często znacząco różnią się usposobieniem i charakterem, a wszelkie konflikty między soba wyciszaja, nie chcac, by próba rozwiąania problemu uraziła partnera i zakłóciła spokój rodziny. W takiej sytuacji dziecko przyjmuje na siebie rolę pośrednika, który poprzez dbałość o dobre samopoczucie obojga rodziców zapewnia harmonię całej rodziny. W rodzinach bulimiczek natomiast częściej obserwuje się napięta atmosferę i nagłe konflikty dotyczace spraw mało istotnych. Reakcje rodziców sa nie tylko wybuchowe, ale też często przeciwstawne: zachowanie dziecka wywołuje aprobatę jednego rodzica i naganę drugiego, co powoduje, że dziecko próbuje zachowywać się idealnie $z$ punktu widzenia obojga rodziców. Wskazuje się, że dla anorektyczek większą rolę odgrywa więź z matką, a dla bulimiczek, z ojcem (NowAK 2013). 
W rozwoju ED moga odgrywać rolę czynniki genetyczne i neurobiologiczne (TozzI i współaut. 2003, DOBRZYŃSKA i RYMASZEWSKA 2006). Jednoczesne występowanie jadłowstrętu zaobserwowano u 12\% bliźniąt dwujajowych oraz u 57\% bliźniąt jednojajowych (DOBRZYŃSKA i RYMASZEWSKA 2006). U osób cierpiących na anoreksję zaobserwowano obniżoną aktywność dopaminy, serotoniny i noradrenaliny, co wywołuje zmiany w regulacji łaknienia, przyjmowania pokarmów, wydzielania hormonów oraz odgrywa rolę w występowaniu zachowań kompulsywnych i stanów lękowych. Zmienione jest funkcjonowanie układu nagrody, którego pobudzenie $u$ osób zdrowych wiąże się $z$ euforia, natomiast u anorektyków wywołuje lęk (PRZEWOŹNIK 2013).

Wskazuje się na możliwą rolę mikrobioty jelitowej zarówno w patogenezie, jak i leczeniu zaburzeń odżywiania, jak również na negatywny wpływ samych zaburzeń odżywiania na skład i różnorodność mikroflory jelitowej, co prowadzi do pogłębienia problemów zdrowotnych (LAM i współaut. 2017, KARAKUŁA-JuCHNOWICZ i współaut. 2017). Stres fizyczny i psychiczny oraz ograniczenie przyjmowania pokarmów prowadza do zwiększenia przepuszczalności bariery jelitowej, co z kolei skutkuje translokacja bakterii poza światło jelita i aktywacją układu odpornościowego. Stres powoduje również zmiany w składzie mikrobioty jelitowej: maleje liczba bakterii $z$ rodzaju Bacteroides, a rośnie liczba bakterii Clostridium (FETISSOV i DECHELOTTE 2011). Białka niektórych bakterii, wirusów i grzybów występujących w jelicie charakteryzuja się występowaniem odcinków homologicznych do neuropeptydow odpowiedzialnych za kontrolę głodu oraz emocji, stąd zmiany w składzie mikrobioty moga wpływać na aktywność tych neuropeptydów (FETISSOV i współaut. 2008). Niektóre substancje bakteryjne, jak lipopolisacharyd i flagelina, poprzez wiazanie $z$ odpowiednimi receptorami, modyfikuja sekrecję hormonów regulujących uczucie głodu i sytości. Suplementacja probiotyków wydaje się być korzystna nie tylko w redukcji objawów jelitowo-żołądkowych towarzyszacych ED, ale także w zmniejszaniu nasilenia stanów lękowych i depresyjnych (LAM i współaut. 2017). Obszar ten wymaga dalszych badań celem określenia zmian w składzie mikrobioty $\mathrm{w}$ różnych typach zaburzeń odżywiania oraz oceny możliwości terapeutycznych.

\section{POSTRZEGANIE ZABURZEŃ ODŻYWIANIA PRZEZ SPOŁECZEŃSTWO}

Sposób, w jaki społeczeństwo postrzega zaburzenia odżywiania oraz osoby na nie cierpiące, może wpływać na proces leczenia. Szczególnie duże znaczenie ma podejście rodziny i przyjaciół. Choć w środowisku medycznym wiedza dotycząca ED znacznie wzrosła w ostatnich latach, nastawienie społeczeństwa wciąż jest oparte na stereotypach i chorzy często bywaja stygmatyzowani przez swoje otoczenie. Stereotypy głęboko zakorzenione w świadomości społecznej sa trudne do usunięcia, stąd też sposób postrzegania ED uległ tylko niewielkim zmianom na przestrzeni lat (MroczKowsKA 2012).

Większość opinii dotyczących zaburzeń odżywiania jest negatywna. Chorzy postrzegani sa jako osoby nieprzystępne, izolujące się, z którymi ciężko nawiąać i utrzymać kontakt. Przypisuje się im niska aktywność społeczną. Przekonania chorych na temat żywienia, żywności czy wyglądu ciała określane bywaja jako fanaberia czy bierne poddawanie się modzie. Dodatkowo, wiele osób nie dostrzega złożoności problemu ED sądząc, że chorzy sa odpowiedzialni za swój stan i winni wystapieniu choroby, a jej utrzymywanie się i wszelkie trudności w leczeniu wynikają $z$ braku starań ze strony chorych. Bagatelizowane przez społeczeństwo sa też inne problemy (rodzinne, stosunki $z$ rówieśnikami itp.), $z$ którymi borykaja się chorzy, a jak wiadomo, to właśnie one sa główną przyczyną wystapienia objawów. Jednym $z$ najbardziej niekorzystnych dla procesu leczenia przekonań jest to o wstydliwości problemu (MroczKowsKA 2012).

W kontraście do opisanych wyżej stereotypowych opinii dotyczacych zaburzeń odżywiania stoja zjawiska takie jak thinspiration, pro-ana czy pro-mia, zyskujace w ostatnim czasie coraz większa popularność (PILECKI i współaut. 2012). Thinspiration polega na umieszczaniu na portalach społecznościowych i stronach internetowych poświęconych tematyce ED treści promujących nadmiernie szczupłe ciało oraz zachowania charakterystyczne dla zaburzeń odżywiania, które maja takie ciało zapewnić. Treści te zazwyczaj mają formę zdjęć lub filmów (GHAZNAVI i TAYLOR 2015). Pro-ana (od pro-anorexia) i pro-mia (od pro-bulimia) to określenia stosowane do opisu społeczności internetowych zrzeszajacych osoby chore na zaburzenia odżywiania oraz osoby bez postawionej diagnozy, ale dażace do znacznej utraty masy ciała $i$ wykazujace te same zachowania co bulimicy i anorektycy. Na portalach tego typu można znaleźć informacje dotyczace technik redukcyjnych, sposobów ukrywania choroby przed rodzina i lekarzem, treści motywujace do zachowań anorektycznych/bulimicznych czy przedstawiajace te zaburzenia jako zjawiska całkowicie zdrowe i normalne. Członkowie społeczności moga dzielić się swoimi 
sukcesami i porażkami na drodze do uzyskania wymarzonej sylwetki oraz udzielać sobie wzajemnie rad (BOERO i PASCOE 2012). Zjawiska te moga wpływać na zwiększenie liczby zachorowań oraz utrudniać postawienie diagnozy i proces leczenia.

Niezwykle istotne jest, by otoczenie wykazywało zrozumienie wobec problemu i wspierało chorego w terapii, gdyż warunkuje to jej skuteczność. Bagatelizowanie choroby, uznawanie jej za „widzimisię" czy nadmierny nacisk na konieczność szybkiego przyrostu masy ciała bez rozwiazania towarzyszacych problemów natury psychicznej moga spowolnić leczenie i zmniejszyć jego efektywność. $Z$ kolei udział w społeczności typu pro-ana może pogłębić objawy choroby i utwierdzić chorego w przekonaniu, że jego poglądy i obraz ciała sa słuszne.

\section{ŻARŁOCZNOŚĆ PSYCHICZNA (BULIMIA PSYCHICZNA)}

\section{OBJAWY, PRZEBIEG I POWIKŁANIA}

Wyróżnia się 2 typy żarłoczności psychicznej: przeczyszczajacy, charakteryzujacy się stosowaniem środków przeczyszczających lub prowokowaniem wymiotów, oraz nieprzeczyszczajacy, w którym epizody bulimii kompensowane sa głodzeniem lub intensywna aktywnościa fizyczna (GUSTEK i JAWORSKI 2011).
Bulimia najczéściej pojawia się w okresie dojrzewania, a choruja osoby, które trzymaja się restrykcyjnych zasad, by uniknąc przyrostu masy ciała. Napady żarłoczności występuja na przemian $z$ okresami normalnego laknienia. Chorzy zazwyczaj ukrywaja przed swoim otoczeniem zarówno epizody przejadania sie, jak i stosowanie metod kompensacyjnych. Podczas epizodów bulimicznych chorzy spożywaja bardzo duże ilości jedzenia, a nastepnie prowokuja wymioty czy zażywaja środki przeczyszczające, by ochronić się przed przytyciem. Zamiast stosowania takich preparatów, bulimicy moga rozpoczać głodówkę lub nadmiernie intensywne ćwiczenia fizyczne (PILCH i współaut. 2011). Kryteria diagnostyczne bulimii przedstawiono w Tabeli 1.

Choroba ma charakter przewlekły i prowadzi do licznych komplikacji. Większość powikłań żarłoczności psychicznej spowodowana jest nadużywaniem środków przeczyszczających i wywoływaniem wymiotów. Pierwszymi pojawiajaccymi się objawami bulimii sa problemy $z$ zębami i dziąsłami, występuja już po 6 miesiacach od rozpoczęcia regularnego prowokowania wymiotów. Wynikaja one $\mathrm{z}$ częstego kontaktu zębów $\mathrm{z}$ kwasem żołąkowym. Próchnica dodatkowo powodowana jest przez duże spożycie produktów wysokowęglowodanowych podczas epizodów żarłoczności, przy jednoczesnym zaniedbaniu higieny jamy ustnej. Kserostomia (suchość

Tabela 1. Kryteria diagnostyczne żarłoczności psychicznej (wg WHO 2012, APA 2013, MoND 2013).

Kryteria diagnostyczne BN wg ICD-10
Występowanie nawracających napadów przejadania
się, co najmniej 2 razy w tygodniu przez 3 miesiące,
podczas których w krótkim czasie spożywane są duże
ilości pokarmu
Nadmierna i uporczywa koncentracja uwagi na jedze-
niu oraz silne pragnienie lub przymus jedzenia
niu oraz silne pragnienie lub przymus jedzenia

Zachowania kompensacyjne po epizodach żarłoczności zapobiegające przyrostowi masy ciała: prowokowanie wymiotów, stosowanie środków przeczyszczających, diuretyków, hormonów tarczycy, preparatów tłumiących łaknienie, poszczenie

Zaburzony obraz ciała, postrzeganie siebie jako osoby Masa i kształt ciała nadmiernie wpływaja na samoocenę otyłej, strach przed przybraniem masy ciała
Kryteria diagnostyczne BN wg DMS-V

Nawracajace epizody kompulsywnego przejadania się,

charakteryzujące się dwiema cechami:

spożycie w określonej jednostce czasu (np. 2 godziny) ilości pożywienia, która w tym samym czasie i w podobnych warunkach byłaby zbyt duża do spożycia dla większości ludzi

brak kontroli podczas epizodu

Nawracajace zachowania kompensacyjne zapobiegające przyrostowi masy ciała: prowokowanie wymiotów, nadużywanie środków przeczyszczających, wymiotnych, moczopędnych, poszczenie, intensywne ćwiczenia fizyczne

Napady żarłoczności i zachowania kompensacyjne pojawiają się co najmniej 2 razy w tygodniu przez 3 miesiące Zaburzenia nie występują jedynie podczas epizodów anoreksji psychicznej 
w jamie ustnej) z kolei wynika ze zmniejszonego wydzielania śliny. Wywoływanie wymiotów powoduje, że cały przewód pokarmowy ma częsty kontakt $z$ kwaśnym sokiem żołądkowym i ulega podrażnieniu. Częste wymioty prowadza do odwodnienia oraz utraty elektrolitów, zwłaszcza potasu, co stwarza niebezpieczeństwo zaburzeń pracy serca. Podobny efekt wywołuje stosowanie środków przeczyszczajacych. Przewlekłe stymulowanie jelit preparatami przeczyszczajacymi powoduje, że ich naturalna perystaltyka zanika, a warstwa mięśniowa ulega atrofii. Po zaprzestaniu stosowania środków przeczyszczajacych pojawiaja się zaparcia, dlatego chorzy często do nich wracaja (MEHLER i RYLANDER 2015).

W przebiegu bulimii często pojawiają się zaburzenia cyklu menstruacyjnego, ale zanik miesiączki występuje rzadko. Ze względu na obniżony poziom hormonu luteinizujacego, u chorych moga pojawić się trudności $z$ zajściem w ciążę. Ryzyko poronień jest nieco wyższe niż u kobiet zdrowych, ale liczba przedwczesnych porodów kształtuje się na podobnym poziomie (CROW i współaut. 2002).

\section{TERAPIA I LECZENIE ŻYWIENIOWE}

Leczenie bulimii powinno być prowadzone przez zespół specjalistów, złożony z lekarza internisty, psychoterapeuty, psychiatry i dietetyka oraz obejmować psychoterapię, farmakoterapię, leczenie żywieniowe i leczenie powikłań. Wśród metod psychoterapeutycznych najlepsze efekty przynosi terapia poznawczo-behawioralna. $\mathrm{W}$ farmakoterapii stosowane sa przede wszystkim leki przeciwdepresyjne, w tym selektywne inhibitory wychwytu zwrotnego serotoniny, zwłaszcza fluoksetyna (GUSTEK i JAWORSKI 2011, OzIER i współaut. 2011).

Niezrównoważona dieta i nieprawidłowe nawyki żywieniowe prowadza do niedoborów pokarmowych i rozwoju niedożywienia, nawet jeśli wskaźnik BMI pozostaje w normie. Jednocześnie, u niektórych pacjentów (ok. $10 \%)$ można spotkać się $\mathrm{z}$ tzw. „maskowana otyłością, gdy przy prawidłowym wskaźniku BMI występuja zmienione proporcje składu ciała, $z$ podwyższeniem odsetka zawartości tkanki tłuszczowej $\geq 33 \%$ i obniżeniem masy mięśniowej. Zadanie dietetyka $\mathrm{w}$ terapii bulimii polega na ocenie stanu odżywienia, sposobu żywienia, rodzaju patologicznych zachowań żywieniowych i zapotrzebowania na makro- i mikroskładniki pokarmowe oraz opracowaniu na podstawie tej oceny planu żywieniowego, mającego na celu eliminację niedoborów i przywrócenie optymalnego stanu odżywienia (OzIER i współaut. 2011). Prawidłowe odżywienie organizmu umożliwia właściwe funkcjonowanie mózgu, co $z$ kolei warunkuje sukces leczenia. W wyniku nadużywania środków przeczyszczających i prowokowania wymiotów dochodzi do zaburzenia gospodarki wodno-elektrolitowej, dlatego istotne jest uwzględnienie $\mathrm{w}$ planie żywieniowym odpowiedniej ilości płynów. Również wszystkie makroskładniki powinny być dostarczone $\mathrm{w}$ ilości zgodnej $\mathrm{z}$ zapotrzebowaniem. Wysokie spożycie węglowodanów może wpłynać na redukcję napadów przejadania się i związanych $z$ nimi zachowan kompensacyjnych. Efekt ten zaobserwowano $u$ osób, które wykazuja znaczną wrażliwość na wszelkie zmiany w syntezie neuroprzekaźników. $Z$ kolei do produkcji hormonów i neuroprzekaźników sa niezbędne aminokwasy, natomiast zarówno białko, jak i tłuszcz zapewniaja uczucie sytości i ograniczają chęć sięgnięcia po przekąskę pomiędzy zaplanowanymi posiłkami (GUSTEK i JAWORSKI 2011).

Do celów terapii w przebiegu żarłoczności psychicznej należą: poprawa stanu odżywienia, edukacja żywieniowa, zapobieganie i leczenie powikłań, redukcja lub całkowita eliminacja napadów przejadania i zachowań kompensujących, zwiększenie motywacji chorego do wprowadzenia zmian $\mathrm{w}$ sposobie żywienia, identyfikacja czynników wywołujących epizody bulimiczne i opracowanie nowych metod radzenia sobie ze stresujacymi sytuacjami, zmiana dysfunkcjonalnych postaw i myśli (GUSTEK i JAWORSKI 2011).

\section{JADEOWSTRET PSYCHICZNY (ANOREKSJA PSYCHICZNA)}

\section{OBJAWY, PRZEBIEG I POWIKŁANIA}

Pierwsze objawy anoreksji psychicznej (ang. anorexia nervosa, AN) sa niespecyficzne, zazwyczaj nie budza podejrzeń i sa postrzegane jako naturalne zjawiska towarzyszace dojrzewaniu, co utrudnia wczesne rozpoznanie choroby. Niezadowolenie $z$ wygladu własnego ciała powoduje, że chory zaczyna odczuwać wyrzuty sumienia po spożyciu posiłku, zwłaszcza obfitego, co skłania go do wdrożenia ograniczeń dietetycznych i zmniejszenia wartości energetycznej potraw. Kolejnymi podejmowanymi krokami sa: unikanie spożywania posiłków $z$ rodzina, chowanie jedzenia, ciagłe liczenie kalorii, intensywne ćwiczenia fizyczne, stosowanie środków moczopędnych lub przeczyszczajacych, wywoływanie wymiotów. Zazwyczaj chorzy próbuja ukryć swoje „nieidealne” ciało poprzez noszenie luźnej odzieży. Stopniowo pogorszeniu ulegaja stosunki $z$ rodzina $i$ innymi bliskimi osobami. Charakterystyczne dla anorektyków jest to, że nie maja poczucia własnej choroby, a swój stan postrzegaja jako normalny 
i naturalny. Nie dostrzegaja lub zaprzeczaja wszelkim dolegliwościom somatycznym, które pojawiaja się jako następstwo anoreksji (DOBRZYŃSKA i RYMASZEWSKA 2006, BATOR i współaut. 2011). Chorobie towarzysza stany lękowe i zespół depresyjny (DOBRZYŃSKA i RYMASZEWSKA 2006).

Kryteria rozpoznania przedstawione zostały w Tabeli 2. Jadłowstręt psychiczny atypowy, uwzględniony $\mathrm{w}$ klasyfikacji ICD10 , rozpoznaje się, gdy nie występuje któryś $z$ wyżej wymienionych objawów lub gdy występuja wszystkie, lecz $\mathrm{w}$ niewielkim nasileniu (LEwITT i współaut. 2008).

Konsekwencje restrykcji dietetycznych sa wielonarządowe, a ostatecznie dochodzi do wyniszczenia organizmu. Niedostateczne spożycie składników mineralnych prowadzi do hipokaliemii, hiponatremii, hipokalcemii, hipofosfatemii, hipomagnezemii oraz innych niedoborów. Zaburzona $\mathrm{w}$ ten sposób równowaga kwasowo-zasadowa i wodno-elektrolitowa może skutkować wystapieniem obrzęków oraz rozwojem niewydolności nerek, a także zaburzeniami rytmu serca. Zmiany w anatomii mózgu zależne sa od czasu trwania choroby $i$ jej nasilenia. U chorych na anoreksję dochodzi do zaniku istoty szarej i istoty białej oraz do zwiększenia objętości płynu mózgowo-rdzeniowego. Zmiany te sa tym większe, im niższy jest wskaźnik BMI. Redukcja istoty szarej dotyczy przede wszystkim obszarów móżdżku, jądra ogoniastego, podwzgórza oraz płatów czołowego, ciemieniowego i skroniowych. Zmiany w jadrze ogoniastym sa przyczyna zaburzeń koncentracji i pamięci, depresji oraz zaburzeń ruchowych, co wykazano m.in. w przebiegu chorób Huntingtona i Parkinsona. Płat czolowy odpowiedzialny jest za abstrakcyjne myślenie, planowanie oraz zachowania zależne od kontekstu, płaty skroniowe za rozpoznawanie obiektów, mowę, odczucia dźwiękowe oraz słuch muzyczny, natomiast płat ciemieniowy integruje zmysły wzroku, słuchu i czucia oraz odpowiada za ruchy celowe i orientacje przestrzenna (PRZEWOŹNIK 2013). Zmniejszenie objętości tkanki mózgu $\mathrm{w}$ tych obszarach skutkuje wystapieniem zachowań charakterystycznych dla anoreksji. Niektórzy badacze sugeruja, że neuropatologie te moga mieć charakter pierwotny i predysponować do rozwoju jadłowstrętu (DoBRZYNNSKA i RYMASZEWSKA 2006).

Istotnym objawem i jednocześnie powikłaniem AN jest zanik miesiaczki. U dziewcząt, które zachorowały na anoreksje przed menarche, następuje pierwotny brak miesiączki oraz zahamowanie pokwitania. Sytuacja taka dotyczy 4-10\% chorych. Rozwój jadłowstrętu po wystapieniu pierwszej miesiączki prowadzi do jej wtórnego zaniku i do zahamowania dojrzewania płciowego. Efekty te przypisywane sa wyniszczeniu zwiazanemu $\mathrm{z}$ AN, choć u 1/3-1/2 chorych brak miesiączki poprzedza znaczaca utrate masy ciała. Wymienia się wiele przyczyn zaniku krwawień miesięcznych, w tym: zaburzenia osi pod-

Tabela 2. Kryteria diagnostyczne jadłowstrętu psychicznego wg ICD-10 i DMS-V (wg LEWITT i współaut. 2008, WHO 2012, APA 2013).

\footnotetext{
Kryteria diagnostyczne AN wg ICD-10 Kryteria diagnostyczne AN wg DMS-V

Masa ciała co najmniej $15 \%$ poniżej oczekiwanej lub wskaźnik $\mathrm{BMI} \leq 17,5$ Ograniczenie poboru energii w stosunku do zapotrzebowania, skutkujące masa ciała niższą niż minimalna normalna

Utrata masy ciała spowodowana ograniczeniami w dieOdczuwanie intensywnego lęku przed przyrostem masy cie oraz stosowanie co najmniej jednej $z$ wymienionych ciała i otyłościa lub zachowania powstrzymujące przymetod: wyczerpujace ćwiczenia fizyczne, zażywanie rost masy ciała, pomimo widocznej niedowagi środków przeczyszczających, moczopędnych i/lub thumiących łaknienie, prowokowanie wymiotów
}

Zaburzony obraz własnego ciała oraz lęk przed otyłością

Zaburzony obraz własnego ciała, jego masy i kształtu, zaprzeczanie istniejacej niedowadze i jej konsekwencjom zdrowotnym, nadmierny wpływ masy ciała na samooce-

Zaburzenia hormonalne dotyczace przysadki, nadnerczy oraz gonad, wywołujące spadek potencji i libido u mężczyzn oraz zatrzymanie miesiaczkowania u kobiet

Rozwój choroby przed okresem pokwitania powoduje opóźnienie lub zahamowanie dojrzewania płciowego 
wzgórze-przysadka-nadnercza oraz obniżenie stężeń progesteronu, estradiolu, LH i FSH, hipogonadyzm hipogonadotropowy, zmiany w wydzielaniu leptyny $\mathrm{i}$ insulinopodobnego czynnika wzrostu IGF-1. W sytuacji niedożywienia czy wyniszczenia, spadek stężenia leptyny może stanowić dla ośrodkowego układu nerwowego sygnał o małej zawartości tkanki tłuszczowej $w$ organizmie $i$ hamować oś gonadalna celem ochrony kobiety przed wydatkowaniem dodatkowej energii na utrzymanie ciąży lub krwawienia miesięczne. Niska masa ciała anorektyczek jest nie tylko przyczyna zahamowania miesiaczek, ale również regresji narząów płciowych. Uzyskanie optymalnej masy ciała i zawartości tkanki tłuszczowej w organizmie wiaże się $z$ powrotem narzadów do stanu sprzed choroby, natomiast brak miesiaczki utrzymuje się u 6-44\% dziewczat i kobiet pomimo spełnienia tych warunków (JAGIELSKA i współaut. 2010).

Zanik miesiaczkowania jest jedna $z$ przyczyn występowania osteoporozy u chorych na jadłowstręt psychiczny. 17-67\% anorektyczek ma obniżona gęstość mineralna kości (ang. bone mineral density, BMD), przy czym wartość tego wskaźnika jest wyższa $\mathrm{u}$ chorych na jadłowstręt atypowy $z$ zachowana miesiaczką. Im dłużej utrzymuje się brak krwawień miesięcznych, tym większa jest utrata masy kostnej oraz wyższe ryzyko złamań osteoporotycznych, króre jest 7 razy wyższe u chorych na AN w porównaniu $z$ kobietami zdrowymi. Anoreksja powoduje rozwój osteoporozy, nie wykazano natomiast częstszego występowania osteomalacji. W przypadku, gdy jadłowstręt rozwiną się w okresie dojrzewania, a nie w dorosłości, chory uzyskuje niższa szczytowa masę kostna. Do innych przyczyn osteoporozy w przebiegu anoreksji należą: niska masa ciała, restrykcje żywieniowe i niedobory wapnia, witaminy D oraz białka, obniżone stężenie czynnika IGF-1 i estrogenu, wysokie stężenie kortyzolu, zaburzenia w wydzielaniu leptyny. Niska podaż wapnia $z$ dieta oraz zmniejszone wchłanianie tego składnika w przewodzie pokarmowym w wyniku niedożywienia powoduja powstanie ujemnego bilansu wapniowego, sprzyjajacego rozwojowi osteoporozy (SzYMAŃSKA i współaut. 2007).

\section{TERAPIA I LECZENIE ŻYWIENIOWE}

Leczenie jadłowstrętu psychicznego jest procesem długotrwałym, wymagajacym współpracy zespołu terapeutycznego, złożonego $z$ internisty, psychiatry, psychoterapeuty, dietetyka oraz fizjoterapeuty i lekarzy specjalistów, zależnie od występujących objawów. Pierwszym elementem leczenia jest zabezpieczenie przed stanem zagrożenia życia, przeciwdziałanie wyniszczeniu, odwodnieniu i zaburzeniom elektrolitowym. Kolejnym krokiem jest normalizacja masy ciała i leczenie konsekwencji niedożywienia, a następnie praca nad zaprzestaniem zachowań kompensacyjnych, zaburzonym sposobem myślenia, relacjami $z$ otoczeniem oraz edukacja żywieniowa. Jeśli masa ciała wynosi mniej niż $75 \%$ należnej, konieczna jest hospitalizacja celem przywrócenia podstawowych funkcji organizmu i zapobieżenia śmierci głodowej. Odmowa podjeccia terapii przez chorego w stanie zagrożenia życia jest podstawa do zastosowania leczenia przymusowego (DOBRZYŃSKA i RYMASZEWSKA 2006, LEWITT i współaut. 2008, BATOR i współaut. 2011).

Podstawę leczenia stanowi psychoterapia. Najczęściej stosowana jest terapia indywidualna i metoda dodatkowa (terapia grupowa lub rodzinna). Leczenie psychologiczne powinno być wdrożone od samego początku, gdyż anoreksja jest przede wszystkim zaburzeniem w funkcjonowaniu sfery emocjonalnej i psychicznej (CARSON 2005, GABBARD 2015). Stosowana jest także farmakoterapia, choć ma ona nieco mniejsze znaczenie. W przypadku wystapienia objawów psychopatologicznych właczane sa odpowiednie leki przeciwpsychotyczne lub przeciwdepresyjne, np. mianseryna, fluwoksamina, klomopromina (GABBARD 2015). Przy obniżonej gęstości mineralnej kości zaleca się suplementację wapnia i witaminy D. Terapia hormonalna jest dyskusyjna, gdyż nie zawsze przynosi oczekiwane efekty, niemniej jednak preparaty hormonalne sa często stosowane w przypadku braku miesiączki pomimo osiagnięcia należnej masy ciała (DOBRZYŃSKA i RYMASZEWSKA 2006, LEWITT i współaut. 2008, BATOR i współaut. 2011).

Drugim, obok psychoterapii, fundamentalnym elementem posteppowania w przebiegu jadłowstrętu psychicznego jest leczenie żywieniowe. W zależności od stanu chorego, odżywianie może odbywać się doustnie, dojelitowo, poprzez sondę dożoładkowa lub parenteralnie (pozajelitowo). Odżywianie doustne jest procesem fizjologicznym, który stwarza nieduże ryzyko powikłań i korzystnie wpływa na prace przewodu pokarmowego, stąd jest to metoda zalecana chorym o niewielkim stopniu niedożywienia, a jeśli stan na to pozwala, także chorym znacznie niedożywionym. Jeśli niemożliwe jest dostarczenie pełnej porcji pokarmowej droga doustna, stosowane jest dożywianie pozostałymi metodami. Leczenie żywieniowe powinno zostać rozpoczęte po dokonaniu oceny stanu odżywienia, sposobu żywienia oraz zapotrzebowania na energie, makro- i mikroskładniki pokarmowe (LEWITT i współaut. 2008). Przyrost masy ciała powinien wynosić $0,5-1 \mathrm{~kg} / \mathrm{ty}-$ 
dzień przy leczeniu ambulatoryjnym (KoHN i współaut. 2011, O’CONNOR i NICHOLLS 2013). Zbyt szybkie zwiększenie wartości energetycznej diety oraz objętości posiłków może skutkować wystapieniem zespołu realimentacyjnego, w skład którego wchodza m.in.: niewydolność krażenia, niewydolność oddechowa, zaburzenia rytmu serca, zatrzymanie krażenia, zaburzenia świadomości, drgawki, parestezje, porażenia, niedrożność porażenna jelit, wymioty (PÜSKÜLLÜOČGLU i współaut. 2011, MALCZYK i OŚWIÉcIMSKA 2017). Brak jest spójnych rekomendacji co do wartości energetycznej diety $\mathrm{w}$ poczatkowych etapach leczenia AN, według zaleceń europejskich powinno być to $5-20 \mathrm{kcal} / \mathrm{kg}$ m.c., natomiast według amerykańskich 30-40 kcal/kg m.c. (MALCZYK i OŚWIËCIMSKA 2017). Wskazuje się na konieczność stopniowego zwiększania podaży energii tak, by uniknać wystapienia zespołu realimentacyjnego (O'CONNOR i NiCHOLLS 2013). Najnowsze publikacje naukowe sugeruja, że w zapobieganiu zespołowi realimentacyjnemu ma znaczenie nie tyle kaloryczność diety, co zawartość w niej węglowodanów. Ograniczenie ich spożycia ma działanie zapobiegawcze, co zwiazane jest $z$ brakiem skoków wydzielania insuliny odpowiedzialnych za zaburzenia gospodarki elektrolitowej (O'CONNOR i NichOLLS 2013).

Powrót krwawień menstruacyjnych jest uważany za miare powrotu do zdrowia (LEWITT i współaut. 2008).

\section{NIESPECYFICZNE ZABURZENIA ODŻYWIANIA}

Zaburzenia odżywiania sa szeroka grupa chorób, do których poza klinicznymi i subklinicznymi postaciami anoreksji i bulimii należa m.in.: bigoreksja, ortoreksja (MicHALSKA i współaut. 2016), pica, zespół przeżuwania (ruminacji), ograniczanie lub unikanie przyjmowania pokarmów, zespół kompulsywnego objadania się, zespół jedzenia nocnego (APA 2013, MichalsKa i współaut. 2016). Poniżej przedstawione zostały ortoreksja i bigoreksja.

\section{ORTOREKSJA}

Ortoreksja charakteryzuje się obsesyjnym zainteresowaniem i poświęcaniem uwagi zdrowej diecie. Choroba ta nie jest zaliczona do zaburzeń odżywiania zarówno wg ICD-10, jak i DSM-5, gdyż istnieją wątpliwości czy prawidłowe byłoby właczenie jej do tej grupy czy też do zaburzeń obsesyjno-kompulsyjnych (JANAS-KOZIK i współaut. 2012, MichalsKa i współaut. 2016).

Poczatkowo chorzy wykluczaja ze swojej diety te produkty, które ich zdaniem moga zaszkodzić zdrowiu ze względu na wysoki stopień przetworzenia, obecność dodatków do żywności lub możliwość zanieczyszczenia metalami ciężkimi, środkami ochrony roślin i innymi substancjami. $Z$ czasem troska o zdrowie urasta do rozmiaru obsesji. Planowanie posiłków, poszukiwanie ekologicznych produktów, przygotowywanie potraw „bezpiecznych" staje sie podstawą życia chorego. Nawet najmniejsze odstępstwo od diety budzi poczucie winy czy nawet odraze do swojej osoby, dlatego wielu ortorektyków wyznacza sobie kary za złamanie zasad. W skrajnych przypadkach chorzy decyduja się na głodowanie zamiast spożycia nieuznawanego przez siebie pokarmu i pija jedynie wodę $z$ pewnego źródła (JANAS-KOZIK i współaut. 2012, DITTFELD i współaut. 2013, VARGA i współaut. 2014, KOVEn i ABRY 2015, MiCHALSKA i współaut. 2016).

Ortoreksja dotyczy $7 \%$ populacji (MICHALSKA i współaut. 2016), częściej występuje wśród osób o wysokiej aktywności fizycznej, która również ma na celu utrzymanie zdrowia, a także u osób, które dąża do osiagnięcia sylwetki promowanej w mediach (DITTFELD i współaut. 2013).

Skutki ortoreksji obejmuja:

- wycofanie społeczne, spowodowane zrywaniem kontaktów $z$ osobami niepodzielajacymi zasad chorego lub je krytykującymi i unikanie wyjść do restauracji czy barów;

- niedożywienie w wyniku eliminacji wielu produktów spożywczych;

- niedobory białka, witaminy B12, żelaza, sodu;

- spadek masy ciała, jeśli restrykcje żywieniowe dotycza nie tylko jakości, ale i ilości pokarmu;

- rabdomiolizę (zespół objawów chorobowych wywołanych masywnym rozpadem tkanki mięśniowej poprzecznie prażkowanej);

- kwasice metaboliczna;

- podwyższone stężenia enzymów wątrobowych i bilirubiny (JANAS-KOZIK i współaut. 2012, DiTTFELD i współaut. 2013).

Brak jest ujednoliconych kryteriów diagnostycznych ortoreksji. Jedna $z$ metod diagnostycznych zaproponował Steven Bratman, autor pierwszego artykułu o ortoreksji $\mathrm{Z}$ 1997 r. Test Bratmana obejmuje 10 pytań, a udzielenie co najmniej czterech twierdzacych odpowiedzi może sugerować występowanie ortoreksji $u$ danej osoby (JANAS-KoZIK i współaut. 2012, DITTFELD i współaut. 2013). Druga metoda diagnostyczna, funkcjonujaca obecnie na terenie Włoch i Turcji, jest kwestionariusz ORTO-15. Składa się z 15 pytań, które maja określić występowanie i nasilenie zaburzenia. Pozytywny wynik testu i jednoczesne stwierdzenie występowania cech osobowości obsesyjno-kompulsyjnej interpretowane jest jako ortoreksja (JANAS-Ko- 
ZIK i współaut. 2012, DITTFELD i współaut. 2013, VARGA i współaut. 2014).

Podobnie jak w przypadku anoreksji i bulimii, leczenie ortoreksji powinno być prowadzone przez interdyscyplinarny zespół lekarzy, dietetyków i psychoterapeutów (KOVEN i ABRY 2015). Pierwszym elementem terapii jest wprowadzenie racjonalnej diety celem wyrównania niedoborów pokarmowych (KAŁĘDKIEWICZ i DOBOSZYŃSKA 2013). U pacjentów znacznie niedożywionych i o niskiej masie ciała należy zwrócić szczególna uwagę na możliwość wystąpienia zespołu szoku pokarmowego (ang. refeeding syndrome). Podstawa leczenia powinna być psychoterapia poznawczo-behawioralna i psychoedukacja. Pomocne może być zastosowanie technik relaksacyjnych dla zredukowania niepokoju towarzyszącego posiłkom. Leczenie farmakologiczne może być utrudnione $z$ uwagi na niechęć chorych do przyjmowania leków, postrzeganych jako nienaturalne i niezdrowe (KOVEN i ABRY 2015). Niemniej jednak wskazuje się na skuteczność inhibitorów zwrotnego wychwytu serotoniny (MATHIEU 2005) oraz leków przeciwpsychotycznych, jak olanzapina (MOROZE i współaut. 2015).

\section{DYSMORFIA MIEŚSINIOWA (BIGOREKSJA)}

Dysmorfia mięśniowa, potocznie zwana bigoreksja, jest podtypem dysmorficznych zaburzeń ciała, choć trwaja dyskusje nad prawidłowościa tej klasyfikacji i zasadnościa przyłaczenia tej jednostki do zaburzeń obsesyjno-kompulsyjnych lub zaburzeń odżywiania. Wskazuje się na podobieństwa pomiędzy bigoreksja, anoreksja i bulimią: nadmierne zainteresowanie wyglacdem swojego ciała, zaburzone postrzeganie swojego wygladu, dażenie do osiagnięcia wymarzonej sylwetki poprzez dietę i ćwiczenia, brak wglądu w chorobę, zaprzeczanie jej istnieniu. Poczatkowo dysmorfia mięśniowa znana była pod nazwa "odwrócona anoreksja”, wielu chorych cierpiało wcześniej na zaburzenia odżywiania (KLUCZYŃSKA 2014).

Kryteria diagnostyczne choroby to:

- koncentracja na swoim wygladzie, zwłaszcza masie mięśniowej oraz dążenie do poprawy wyglądu poprzez nadmierne ćwiczenia fizyczne i dietę;

- zaniedbywanie życia społecznego celem ścisłego przestrzegania narzuconych ograniczeń i zaplanowanego grafiku;

- unikanie miejsc i sytuacji, w których ciało może być odsłonięte i podatne na ocenienie przez innych (basen, plaża);

- kontynuowanie treningów, rygorystycznej diety oraz stosowanie leków i suplementów pomimo świadomości negatywnych skutków tych działań (MichalsKA i współaut. 2016).
W obrazie choroby dominuje nadmierna koncentracja na rozbudowywaniu masy mięśniowej. Chorzy spędzaja większość swojego czasu na treningach, wykonując głównie ćwiczenia siłowe, takie jak podnoszenie ciężarów. Charakterystyczne jest rygorystyczne stosowanie się do ustalonego planu treningowego, nawet kosztem życia zawodowego i społecznego. Zaplanowane wyjście na siłownię (lub ćwiczenia w domu, jeśli chory boi się wykonywania treningów w miejscach publicznych $z$ uwagi na nikła, w swojej opinii, masę mięśniowa) jest ważniejsze od spotkań towarzyskich, co prowadzi do narastajacej izolacji. Również kontakty seksualne sa przez chorych ograniczane, gdyż moga być postrzegane jako niepotrzebne wydatkowanie energii, która można wykorzystać na ćwiczenia. Wycofanie się $z$ życia społecznego jest też spowodowane ciagłym porównywaniem się $z$ innymi i obawa przed negatywna opinią tych osób na temat wyglądu chorego. Zaniedbywanie obowiazków, częste przerwy celem wykonania choć kilku ćwiczeń lub przygotowania odżywki białkowej sa powodem zwolnień z pracy, dlatego wielu chorych decyduje się na wykonywanie zawodu trenera personalnego, który nie koliduje $z$ ich aktywnościami (Mosley 2009, KLUCZYŃSKA 2014).

Ważnym aspektem bigoreksji jest stosowanie diety oraz zażywanie suplementów i leków, mających na celu przyspieszenie budowy masy mięśniowej. Planowanie posiłków, zakupy określonych produktów, liczenie kalorii, ważenie porcji i pakowanie posiłków do pudełek, by móc je spożyć o wyznaczonej godzinie niezależnie od aktualnego miejsca pobytu, to aktywności, którym chorzy poświęcaja nawet kilka godzin dziennie. Istotny element diety stanowia odżywki i koktajle białkowe (MOSLEY 2009, KLUCZYŃSKA 2014). Nierzadko bigorektycy sięgaja po steroidy androgenno-anaboliczne, będąc przekonanymi o niedostatecznym rozwinięciu swoich mięśni i złym wyglądzie (MĘDRAŚ i SZCZESNY 2004, MOSLEY 2009, KLUCZYŃSKA 2014).

Do skutków dysmorfii mięśniowej należą: izolacja społeczna, problemy zawodowe, uzależnienie od steroidów anabolicznych (MoSLEY 2009, KLUCZYŃSKA 2014). Niepożądane efekty stosowania tych substancji to: atrofia jąder, ginekomastia, podwyższone stężenie cholesterolu, trądzik, przerost gruczołu krokowego, łysienie androgenowe. W przypadku zaprzestania stosowania może rozwinać się depresja, prowadzaca niekiedy do podejmowania prób samobójczych (MOSLEY 2009, MICHALSKA i współaut. 2016).

Leczenie dysmorfii mięśniowej opiera się na terapii psychiatrycznej i psychologicz- 
nej (MEDRAŚ i SZCZESNY 2004, KLUCZYŃSKA 2014). Bigorektycy rzadko postrzegają swój stan jako chorobę, dlatego też nieczęsto zwracaja się po specjalistyczna pomoc. Porady lekarza poszukują zazwyczaj w przypadku depresji lub nadużycia substancji wspomagajacych. Leczenie przebiega zgodnie $z$ zaleceniami dla zaburzeń odżywiania, zaburzeń obsesyjno-kompulsywnych oraz dysmorficznych zaburzeń ciała. Podstawa jest eliminacja zażywania steroidów androgenno-anabolicznych, redukcja czasu poświęcanego na ćwiczenia fizyczne oraz pomoc w dostrzeżeniu rzeczywistego obrazu swojego ciała (KLUCZYŃSKA 2014).

\section{PODSUMOWANIE}

Zaburzenia odżywiania stanowią istotny problem interdyscyplinarny. Poza stosunkowo dobrze już poznanymi zaburzeniami, takimi jak bulimia i anoreksja, coraz częściej mówi się o ortoreksji i bigoreksji, których podłoże może znajdować się we współczesnej modzie na „bycie fit”. Rozpoznawanie pierwszych nieprawidłowych zachowań chorych oraz objawów zaburzenia jest niezwykle istotne, gdyż $\mathrm{w}$ pełni rozwinięta choroba jest trudna do całkowitego wyleczenia.

\section{PODZIE KOWANIA}

Artykuł powstał na podstawie pracy magisterskiej, przygotowanej pod kierownictwem prof. Marka Mędrasia w Akademii Wychowania Fizycznego we Wrocławiu.

\section{Streszczenie}

Zaburzenia odżywiania sa chorobami o złożonej etiologii i przebiegu. Problem ten dotyczy zwłaszcza dziewcząt i młodych kobiet, co może mieć podłoże w społeczno-kulturowym postrzeganiu kobiety. Pogoń za wymarzona sylwetka czy nieumiejętność radzenia sobie $z$ problemami moga prowadzić do wykształcenia zaburzeń takich jak anoreksja, bulimia, ortoreksja czy bigoreksja. Skutki zaburzeń odżywiania dotycza nie tylko zdrowia fizycznego chorych, ale także sfery psychicznej i społecznej. W leczeniu konieczne jest podejście interdyscyplinarne, obejmujące opiekę lekarska, psychologiczna i dietetyczną.

\section{LITERATURA}

APA (American Psychiatric Association), 2013. Diagnostic and statistical manual of mental disorders. American Psychiatric Association, Arlington, V.A.

BATOR E., BRONKOWSKA M., ŚlePECKI D., BIERNAT J., 2011. Anoreksja - przyczyny, przebieg, leczenie. Nowiny Lekarskie 80, 184-191.

BOERO N., PASCOE C. J., 2012. Pro-anorexia communities and online interaction: bringing the pro-ana body online. Body Soc. 18, 27-57.

BRYTEK-MATERA A., 2008. Predyktory dażenia do szczupłości $w$ anoreksji $i$ bulimii psychicznej. Pol. Forum Psychol. 13, 157-165.
CARson R., Butcher J., MineKa S., 2005. Psychologia zaburzeń. Gdańskie Wydawnictwo Psychologiczne, Gdańsk.

Crow S. J., Thuras P., KeEl P. K., Mitchell J. E., 2002. Long-term menstrual and reproductive function in patients with bulimia nervosa. Am. J. Psychiat. 159, 1048-1050.

DitTFEld A., KOsZOWSKA A., FiZIA K., ZiORA K., 2013. Ortoreksja- nowe zaburzenie odżywiania. Ann. Acad. Med. Silesiensis 67, 393-399.

DOBRZYŃSKA E., RYMASZEWSKA J., 2006. Jadłowstręt psychiczny- ciagłe wyzwanie dla współczesnej medycyny. Psychiatria w Praktyce Ogólnolekarskiej 4, 165-170.

DYCHT M., MARSZAEEK L., 2011. Mass media $i$ reklama a choroby cywilizacyjne: anoreksja $i$ bulimia. Seminare 30, 147-158.

FEtissov S. O., DechelotTe P., 2011. The new link between gut-brain axis and neuropsychiatric disorders. Curr. Opin. Clin. Nutrit. Metab. Care 14, 477-482.

Fetissov S. O., Hamze Sinno M., Coeffier M., BOlE-FEYSOT C., DUCROTTE P., HOKFElT T., DECHELOTTE P., 2008. Autoantibodies against appetite-regulating peptide hormones and neuropeptides: putative regulation by gut microflora. Nutrition 24, 348-359.

FreYberger H. J., SCHNEIDER W., STIEGLitz R. D., 2005. Kompendium psychiatrii, psychoterapii, medycyny psychosomatycznej. Wydawnictwo Lekarskie PZWL, Warszawa.

GABBARD G. O., 2015. Psychodynamic psychiatry in clinical practice. American Psychiatric Press Inc., Waszyngton.

GHAZNAVI J., TAYLOR L., 2015. Bones, body parts, and sex appeal: an analysis of \#thinspiration images on popular social media. Body Image 14, 54-61.

GUSTEK S., JAWORSKI M., 2011. Znaczenie interwencji żywieniowej $w$ psychoterapii poznawczo-behawioralnej $w$ bulimii. Psychiatria i Psychotherapia 7, 7-21.

JAGIELSKA G., WOLAN̂CZYK T., OSUCH B., 2010. Zaburzenia miesiaczkowania $w$ jadłowstrecie psychicznym. Psychiatr. Pol. 44, 277-286.

JANAS-KOZIK M., ZEJDA J., STOCHEL M., BROŻEK G., JANAS A., JELONEK I., 2012. Ortoreksjanowe rozpoznanie? Psychiatr. Pol. 46, 441450.

JÓZEFIK B., 1999. Anoreksja i bulimia psychiczna. Rozumienie $i$ leczenie zaburzeń odżywiania się. Wydawnictwo Collegium Medicum UJ, Kraków.

KAŁEDKIEWICZ E., DoBoszyŃsKA A., 2013. Ortoreksja na tle innych zaburzeń odżywiania. Forum Medycyny Rodzinnej 7, 307-315.

KAPLAN H. I., SADOCK B. J., 2004. Psychiatria kliniczna. Elsevier Urban \& Partner, Wrocław.

KARAKUŁA-JUCHNOWICZ H., PANKOWICZ H., JUCHNOWICZ D., VALVERDE PIEDRA J. L., MAEECKA-MASsALSKA T., 2017. Mikrobiota jelitowaklucz do zrozumienia patofizjologii jadłowstrętu psychicznego? Psychiatr. Pol. 51, 859-870.

KĘDRA E., PIETRAS J., 2011. Zaburzenia odżywiania- znak naszych czasów. Probl. Hig. Epidemiol. 92, 530-534.

KLUCZYŃSKA U., 2014. Bigoreksja, czyli kłopoty mężczyzn $z$ ciałem. [W:] Mężczyźni- kryzys, postęp, zmiana? Tom 11, Część 1. BoUGSIAA H., Kopciewicz L., WELENC M. (red.). Ars Educandi, Wydawnictwo Uniwersytetu Gdańskiego, Gdańsk.

Kohn M. R., MadDEn S., ClaRke S. D., 2011. Refeeding in anorexia nervosa: increased safety and efficiencythrough understanding the 
pathophysiology of protein calorie malnutrition. Curr. Opin. Pediatr. 23, 390-394.

Koszowska A., DiTTFELD A., ZUBELEWICZ-SZKoDZIŃSKA B., 2013. Psychologiczny aspekt odżywiania $i$ wplyw wybranych substancji na zachowania $i$ procesy myślowe. Hygeia Publ. Health 48, 279-284.

Koven N. S., ABRY A. W., 2015. The clinical basis of orthorexia nervos: emerging perspectives. Neuropsych. Disease Treatment 11, 385-394.

LAM Y. Y., MAGUiRE S., PALACIOS T., CATERSON I. D., 2017. Are the gut bacteria telling us to eat or not to eat? Reviewing the role of gut microbiota in etiology, disease progression ant treatment of eating disorders. Nutrients 9, doi:10.3390/nu9060602.

LEWITT A., BRZECZEK K., KRUPIENICZ A., 2008. Interwencje żywieniowe $w$ leczeniu anoreksjiwskazówki dietetyczne. Endokrynologia, Otyłość i Zaburzenia Przemiany Materii 4, 128136.

MALCZYK Ż., OśWIęcimska J., 2017. Powikłania gastroenterologiczne $i$ zasady realimentacji pacjentów $z$ jadłowstrętem psychicznym. Psychiatr. Pol. 51, 219-229.

MAthiEU J., 2005. What is otrhorexia? J. Am. Diet. Assoc. 105, 1510-1512.

Mehler P. S., RYlander M., 2015. Bulimia nervosa- medical complications. J. Eating Disord. 3, doi: 10.1186/s40337-015-0044-4.

MĘDRAŚ M., SZCZESNY M., 2004. Dysmorfofobia (dysmorfia) mięśniowa a sport. [W:] Medycyna sportowa. MÉDRAŚ M. (red.). Agencja Wydawnicza MEDSPORTPRESS, Warszawa.

MichAlSKA A., SZEJKO N., JAKUBCZYK A., WOJNAR M., 2016. Niespecyficzne zaburzenia odżywiania- subiektywny przeglad. Psychiatr. Pol. 50, 497-507.

MikoŁAJCZYK E., SAMOCHOWIEC J., 2014. Cechy osobowości u pacjentek $z$ zaburzeniami odżywiania. Psychiatria 1, 91-95.

MOND J.M., 2013. Classification of bulimic- type eating disorders: from DSM-IV to $D S M-5$. J. Eating Disord. 1, https://doi. org/10.1186/2050-2974-1-33.

Moroze R. M., DunN T. M., CRAIG H. J., YAGeR J., WeINTRAUB P., 2015. Microthinking about micronutrients: a case of transition from obsessions about healthy eating to near-fatal "orthorexia nervosa" and proposed diagnostic criteria. Psychosomatics 56, 397-403.

Mosley P. E., 2009. Bigorexia: bodybuilding and muscle dysmorphia. Eur. Eating Disord. Rev. 17, 191-198.
MroczKowsKA D., 2012. Postrzeganie i rozumienie zaburzeń jedzenia- fakty $i$ mity. Forum Medycyny Rodzinnej 8, 82-91.

NowAK K., 2013. Socjodemograficzne $i$ rodzinne czynniki ryzyka zaburzeń odżywiania młodzieży. Lubelski Rocznik Pedagogiczny 32, 121146.

O'CONNOR G., NICHOLls D., 2013. Refeeding hypophosphatemia in adolescents with anorexia nervosa: a systematic review. Nutrit. Clin. Pract. 28, 358-364.

Ozier A. D., Henry B. W., American Dietetic AsSOCIATION., 2011. Position of the American Dietetic Association: nutrition intervention in the treatment of eating disorders. J. Am. Dietet. Assoc. 111, 1236-1241.

Pilch W., JANisZeWska R., MaKuCh R., Mucha D., PAŁKA T., 2011. Racjonalne odżywianie $i$ jego wpływ na zdrowie. Hygeia Publ. Health 46, 244-248.

PILECKI M., JózefiK B., SAŁAPA K., 2012. Kontekst kulturowy zaburzeń odżywiania sie- badania własne. Psychiatr. Pol. 46, 189-200.

PORYCKA A., 2016. Wokół triady ciało-zdrowie-media (analizy $i$ refleksje). RELACJE. Studia $z$ Nauk Społecznych 2, 75-86.

PRZEWOŹNIK D., 2013. Wybrane zagadnienia dotyczace neurobiologii jadłowstretu psychicznego. Neuropsychiatr. Neuropsychol. 8, 118-122.

PÜSKÜLlÜOČGLU M, NIECKULA J, LAPRUS I., 2011. Zespół ponownego odżywienia $u$ pacjentów $z$ choroba nowotworowa. Onkol. Prakt. Klin. 7, 24-30.

SZYMAŃSKA U., JAGIELSKA G., TOMASZEWICZ-LIBUDZIC C., PRZEDLACKI J., 2007. Zaburzenia metabolizmu kostnego $w$ jadłowstrecie psychicznym. Wiad. Lek. 60, 68-72.

Tozzi F., Sullivan P. F., FEaR J. L., Mckenzie J., BULIK C. M., 2003. Causes and recovery in Anorexia nervosa: the patient perspective. Int. J. Eating Disord. 33, 143-154.

VARGA M., THEGE B. K., DUAKY-SZABÓ S., TÚRY F., VAN FURTH E. F., 2014. When eating healthy is not healthy: orthorexia nervosa and its measurement with the ORTO-15 in Hungary. BMC Psychiatry 14, doi: 10.1186/1471-244X14-59.

Who (World Health Organisation), 2012. Międzynarodowa statystyczna klasyfikacja chorób $i$ problemów zdrowotnych. Rewizja 10, tom 1 . Centrum Systemów Informacyjnych Ochrony Zdrowia. 
KOSMOS Vol. 68, 1, 121-132, 2019

Ewa JABŁońsKa, KARINA BŁĄDKOWsKa, MoniKa BRONKOwsKa

Department of Human Nutrition, Wrocław University of Environmental and Life Sciences, 37 Chełmońskiego Str., 51-630 Wrocław, E-mail: ewa.jablonska@upwr.edu.pl,karina.bladkowska@upwr.edu.pl,monika.bronkowska@upwr.edu.pl

EATING DISORDERS AS HEALTH AND PSYCHOSOCIAL PROBLEMS

\section{Summary}

Eating disorders belong to diseases with a complex etiology and course. They primarily affect adolescent girls and young women, and may have foundation in sociocultural perception of women. The pursuit of a dream body or inability to cope with one's problems may lead to development of disorders such as anorexia, bulimia, orthorexia or bigorexia. The consequences of eating disorders apply not only to physical health, but also to mental state and social sphere. In their treatment, an interdisciplinary approach is needed, consisting of medical, psychological and dietary care.

Key words: anorexia, bigorexia, bulimia, eating disorder, muscle dysmorphy, orthorexia 